\title{
Effects of Coal Tar Dyes on Viability, and RNA and Protein Syntheses in Isolated Rat Hepatocytes*
}

\author{
(Received January 13, 1984)
}

\author{
Makoto Yoshimoto, Kuniaki Noda, Shoji Hatano and Tadao Watanabe \\ (Department of Food Science and Technology, Faculty of Agriculture, Kyushu \\ University: Hakozaki, Higashi-ku, Fukuoka, Japan)
}

\begin{abstract}
The effects of Amaranth, Ponceau 3R, Sunset Yellow FCF, and Rose Bengal on viability and RNA and protein syntheses were studied in suspensions of viable rat hepatocytes. Liver parenchymal cells were enzymatically prepared from normal adult rats by perfusion of the liver with buffer solution of $0.05 \%$ collagenase, followed by shaking of liver slices in the same solution. The cell yield was $60.5 \pm 15.8 \times 10^{8}$ cells/g liver and the cell viability index was 87.0 $\pm 2.4 \%$. When the isolated hepatocytes were incubated in the presence of coal tar dyes at a concentration of $1 \mathrm{mM}$ for $4 \mathrm{hr}$, a decrease in the cell viability was observed. In particular, the Rose Bengal-treated fraction showed a rapid decrease of the cell viability in comparison with other dye-treated fractions. ${ }^{3} \mathrm{H}$-Uridine incorporation into RNA was stimulated in the presence of Amaranth or Ponceau 3R. On the other hand, none of the coal tar dyes tested in this study had any effect on ${ }^{14} \mathrm{C}$-isoleucine incorporation into protein. These results suggest that the system of isolated hepatocytes may be a good model for studying the mechanism of action of toxic chemicals.
\end{abstract}

Key words: rat; isolated hepatocyte; collagenase; viability index; RNA synthesis; protein synthesis; Amaranth; Ponceau 3R; Rose Bengal; Sunset Yellow FCF

\section{Introduction}

It is now recognized that the majority of chemicals require metabolic activation for their toxic potential to be realized and the enzyme activity causing this activation is localized predominantly in mammalian hepatocytes $^{1)}$. Conversely, a number of chemicals are inactivated by metabolism and this activity is also preferentially localized in mammalian hepatocytes ${ }^{1)}$.

Some workers have used primary hepatocyte cultures to study the metabolism of chemicals $^{2-5)}$. These studies have demonstrated that the metabolism of chemicals by isolated viable hepatocytes in suspension close-

* Effects of Coal Tar Dyes on RNA Synthesis (Part 6) ly resembles the in vivo situation. Consequently, the isolated hepatocyte system appears to be a useful model for studies of the in vivo metabolism of chemicals. Therefore, we decided to utilize this cell culture system in studies of the metabolism of food additives.

In our previous paper ${ }^{6)}$, Ponceau 3R, Ponceau $R$ and Amaranth have been shown to stimulate and Rose Bengal to inhibit RNA synthesis in isolated rat liver nuclei. Ponceau $R$ and Ponceau 3R have been banned as food additives, because they have been associated with toxic effects, such as induction of liver injury and tumor formation ${ }^{7)-10)}$. Since Amaranth was first suggested to have carcinogenic properties $^{11}$, various authors have investigated the teratogenic carcinogenic, and toxic effects of Amaranth ${ }^{12)-14)}$. Further, our re- 
cent study has indicated that Ponceau $3 \mathrm{R}$ and Amaranth stimulate RNA synthesis in rat liver after oral administration of the azo days $^{15)}$.

This report describes the effects of Ponceau 3R, Amaranth, Sunset Yellow FCF, and Rose Bengal on viability and RNA and protein syntheses in isolated rat hepatocytes. Sunset Yellow FCF was previously found to have no effect on RNA synthesis in isolated rat liver nuclei ${ }^{(6)}$.

\section{Materials and Methods}

\section{Chemicals and isotopes}

Collagenase (EC 3.4.4.19) was obtained from P-L Biochemicals, Inc., and fetal bovine serum from Sanko Pure Chemicals. Trypan blue was purchased from Chroma Gesellshaft. Ponceau R, Amaranth, Sunset Yellow FCF, and Rose Bengal were obtained from the $\mathrm{Na}$ tional Institute of Hygienic Sciences in Japan. ${ }^{14} \mathrm{C}$-Isoleucine $(321 \mathrm{mCi} / \mathrm{mmole})$ and ${ }^{3} \mathrm{H}$-uridine $(26.6 \mathrm{Ci} / \mathrm{mmole})$ were products of New England Nuclear.

\section{Preparation of rat hepatocyte suspension}

Male rats of the Wistar strain weighing $200 \mathrm{~g}$ to $250 \mathrm{~g}$ were fed a commercial diet obtained from Wako Pure Chemicals Industries, Ltd. and water ad libitum. The procedure for preparing a single cell suspension was a modification of that of Yamasaki and Ichihara $^{18)}$. The abdomen and chest of the rat were opened under ether anesthesia, and the liver was perfused via the portal vein with $30 \mathrm{ml}$ of calcium- and magnesium-free Hanks' solution containing $0.5 \mathrm{~m} M$ ethyleneglycol-bis-( $\beta$ - aminoethylether) $\mathrm{N}, \mathrm{N}^{\prime}$ - tetracetic acid and $20 \mathrm{ml}$ of enzyme solution. The enzyme solution was $0.05 \%$ collagenase dissolved in Hanks' solution ( $\mathrm{pH} 7.2$ ) containing 2\% bovine serum albumin and $10 \mathrm{~m} M$ HEPES. The liver lobes were cut into slices of about $1 \mathrm{~mm}$ in thickness with a Stadie-Riggs tissue slicer. Slices $(3 \mathrm{~g})$ were than placed in a 250 $\mathrm{ml}$ conical flask containing $10 \mathrm{ml}$ of enzyme solution. All procedures to this point were carried out at $4^{\circ} \mathrm{C}$. The flasks were then shaken in a shaking water bath at $37^{\circ} \mathrm{C}$ for $60 \mathrm{~min}$ (120 oscillations/min). The resulting cloudy supernatant was mixed with $20 \mathrm{ml}$ of calcium- and magnesium-free Hanks' solution and filtered through a layer of nylon cloth $(60 \mu \mathrm{m}$ pore size; Noguchi Bolting Cloth, Tokyo) so as to remove large cell clumps and undigested tissues. The filtrate was resuspended in $10 \mathrm{ml}$ of calcium- and magnesiumfree Hanks' solution containing $2 \%$ bovine serum albumin, then centrifuged, and resuspended in incubation medium to give the final cell suspension.

\section{Cell yield and viability}

The viability was based on the ability of cells to exclude trypan blue. Cell suspension, $0.4 \mathrm{ml}$, was mixed with $0.2 \mathrm{ml}$ of $0.5 \%$ trypan blue solution (dissolved in isotonic salt solution) and incubated at $37^{\circ} \mathrm{C}$ for $5 \mathrm{~min}$. Stained and unstained cells were counted with a Thoma hemacytometer.

\section{Incubation and metabolic experiment ${ }^{17}$}

Syntheses of RNA and protein were measured by using ${ }^{3} \mathrm{H}$-uridine and ${ }^{14} \mathrm{C}$-isoleucine as precursors, respectively. The isolated liver cells were suspended in $7 \mathrm{ml}$ of Hanks' solution containing $10 \%$ fetal bovine serum $(\mathrm{pH}$ 7.2). The protein content of the hepatocytes was measured by the method of Lowry ${ }^{18)}$ with crystalline bovine albumin as a standard. The cells were shaken in an incubator at $37^{\circ} \mathrm{C}$ for $5 \mathrm{~min}$, and the experiment was initiated by addition of dyes and labelled precursors. After the desired length of time, the incubation was terminated by pipetting an aliquot of the cell suspension into $10 \mathrm{ml}$ of ice-cold isotonic saline. The cells were sedimented by centrifugation at $1,000 \times \mathrm{g}$ for $10 \mathrm{~min}$ and washed twice with 5\% trichloroacetic acid solution (TCA), followed by two 15-min extractions with $5 \% \mathrm{TCA}$ at $90^{\circ} \mathrm{C}$. Tritium recovered in the supernatant fluid from the hot TCA extractions was used as a measure of RNA synthesis. The resulting precipitates were washed once with ethanol: ether (1:1) and once with ether, then digested with $0.2 \mathrm{~N}$ ammonium hydroxide. The ${ }^{14} \mathrm{C}$ content of the digest was determined and used as a measure of protein synthesis. The radioactivity was counted in a Beckman LS-250 liquid scintillation counter. 
Table 1. Comparison of Viable Cell Yield and Viability Index of Hepatocyte Suspensions Prepared by our Method and That of Fry et al. ${ }^{19)}$

\begin{tabular}{|c|c|c|}
\hline Method used & $\begin{array}{c}\text { Viable cell yield } \\
\left(\times 10^{8} / \mathrm{g} \text { liver }\right)\end{array}$ & $\begin{array}{l}\text { Viability index } \\
(\%)\end{array}$ \\
\hline This paper & $60.4 \pm 15.8^{*}(41-80)$ & $87.0 \pm 2.4 *(84-90)$ \\
\hline Fry et $a l .^{10)}$ & $12.2 \pm 0.7(7.0-19.9)$ & $84 \pm 2 \quad(70-98)$ \\
\hline
\end{tabular}

* Values are expressed as means \pm S.D. of four experiments with the range in brancets

\section{Results and Discussion}

A suspension of rat hepatocytes was prepared by perfusing the liver with dissociation medium and shaking the sliced tissue in dissociation medium. The cell yield and viability of isolated hepatocytes are shown in Table 1. The cell yield of isolated hepatocytes produced by the method described in this paper was $60.4 \pm 15.8 \times 10^{8}$ cells/g liver. The majority $(87.0 \pm 2.4 \%)$ of hepatocytes was viable. These results compare very favorably with the result reported by Fry et al. ${ }^{19)}$ The viability indexes were approximately same but the method employed in this paper gave a markedly increased yield of viable rat hepatocytes. The method of Yamasaki and Ichihara ${ }^{16)}$ is a compromise between the shaking method of Howard $e t a l .{ }^{20)}$ and the perfusion method of Berry ${ }^{21)}$. The only enzyme used for dissociation of liver tissue is collagenase in this method. According to Fry et al. ${ }^{19)}$, the absence of hyaluronidase (EC 3.2.1.35) appeared to decrease the viable cell yield with no loss of viability. On the other hand, Seglen reported that hyaluronidase, an enzyme commonly used in liver perfusion procedures, had no detectable dispersion activity alone and inhibited dispersion at high enzyme concentrations $^{22)}$. Our results also suggest that hyaluronidase is not necessary for dissociation of liver tissue. Important factors in the isolation of viable hepatocytes by the method employed in this work are the accuracy of slicing (as judged by the thickness of the slices) and the perfusion procedures. The effects of coal tar dyes on viability, and RNA and protein syntheses were studied in these cell suspensions.

The effects of duration of incubation on the viability of hepatocytes in the presence or

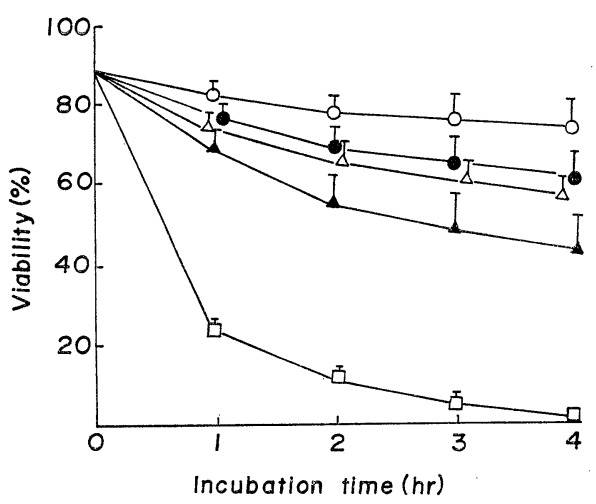

Fig. 1. Effects of coal tar dyes on viability of isolated rat hepatocytes. A hepatocyte suspension $(7 \mathrm{ml})$ containing $2 \times 10^{7}$ cells/ $\mathrm{ml}$ was incubated at $37^{\circ} \mathrm{C}$ for $4 \mathrm{hr}$. Each of the coal tar dyes was added to a final concentration of $1 \mathrm{~m} M$. Aliquots were taken at the indicated times for the determination of viability and processed as described under "Materials and Methods". Each point is a mean of three experiments.

$O$, no addition of dye; 1 , Sunset Yellow FCF; $\triangle$, Amaranth; $\mathbf{\Delta}$, Ponceau 3R; $\square$, Rose Bengal

absence of coal tar dyes is shown in Fig. 1. Each of the coal tar dyes was added to the incubation medium at a final concentration of $1 \mathrm{~m} M$. When the hepatocytes were incubated in the absence of coal tar dyes, a decrease of the cell viability was observed and the viability index fell to $87 \%$ to $75 \%$ after $4 \mathrm{hr}$. The viability index of Sunset Yellow FCF. or Amaranth-treated hepatocytes was approximately $65 \%$ after $4 \mathrm{hr}$. When the hepatocytes were incubated in the presence of Ponceau $3 \mathrm{R}$, the viability index fell to about $50 \%$ after $4 \mathrm{hr}$. A rapid decrease of viability of Rose Bengal-treated hepatocytes was observed, and after $4 \mathrm{hr}$ no viable cells could be found. 


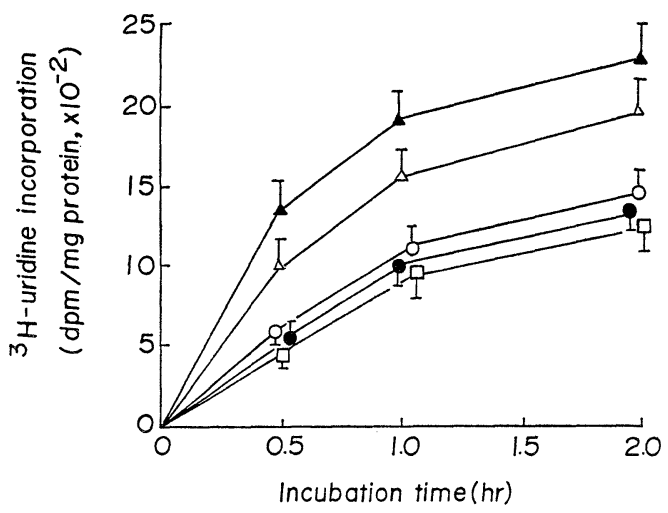

Fig. 2. Effect of coal tar dyes on ${ }^{3} \mathrm{H}$-uridine incorporation into RNA in isolated rat hepatocytes

A hepatocytes suspension $(7 \mathrm{ml})$ containing $2 \times 10^{7}$ cells $/ \mathrm{ml}$ was incubated with $5 \mu \mathrm{Ci}{ }^{3} \mathrm{H}$ uridine at $37^{\circ} \mathrm{C}$ for $2 \mathrm{hr}$. Each of the coal tar dyes was added to a final concentration of $1 \mathrm{~m} M$. Aliquots of $0.5 \mathrm{ml}$ were taken at the indicated times and processed as described under "Materials and Methods". Each point is a mean of three experiments.

$\Delta$, Ponceau 3R; $\triangle$, Amaranth; $\bigcirc$, no addition of dye; $\odot$, Sunset Yellow FCF; $\square$, Rose Bengal

Incorporation of ${ }^{3} \mathrm{H}$-uridine into RNA by the hepatocytes in the presence or absence of coal tar dyes is shown as a function of time in Fig. 2. The incorporation was measured during incubation for up to $2 \mathrm{hr}$. No difference in the incorporation of ${ }^{3} \mathrm{H}$-uridine into RNA could be detected between the control and Sunset Yellow FCF- or Rose Bengal-treated hepatocytes. Both Amaranth- and Ponceau 3R-treated hepatocytes showed higher incorporation than the control.

Incorporation of ${ }^{14} \mathrm{C}$-isoleucine into protein of hepatocytes in the presence or absence of coal tar dyes is shown in Fig. 3. None of the coal tar dyes tested had any effect on the incorporation of ${ }^{14} \mathrm{C}$-isoleucine into protein.

We have reported that Rose Bengal inhibited RNA synthesis in isolated liver nuclei ${ }^{6)}$. In isolated rat hepatocytes, however, this dye had no effect on RNA or protein synthesis. These results suggest that Rose Bengal may not be able to affect the components of nuclei through the barrier of the cytoplasm at the

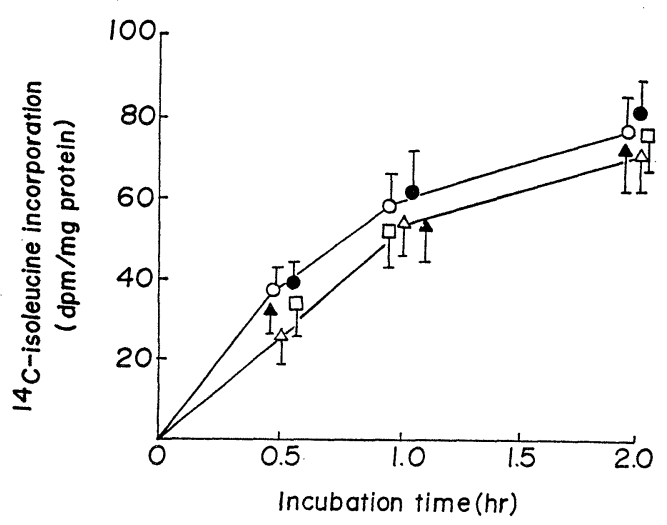

Fig. 3. Effect of coal tar dyes on ${ }^{14} \mathrm{C}$-isoleucine incorporation into protein in isolated rat hepatocytes

A hepatocyte suspension $(7 \mathrm{ml})$ containing $2 \times 10^{7}$ cells $/ \mathrm{ml}$ was incubated with $3 \mu \mathrm{Ci}{ }^{14} \mathrm{C}$ isoleucine at $37^{\circ} \mathrm{C}$ for $2 \mathrm{hr}$. Each of the coal tar dyes was added to a final concentration of $1 \mathrm{~m} M$. Aliquots of $0.5 \mathrm{ml}$ were taken at the indicated times and processed as described under "Materials and Methods." Each point is a mean of three experiments. $\bigcirc$, no addition of dye;, Sunset Yellow FCF; $\square$, Rose Bengal; $\boldsymbol{\Delta}$, Ponceau 3R; $\triangle$, Amaranth

dye concentration used $(1 \mathrm{~m} M)$. Several authors have reported that Rose Bengal strongly binds to various kinds of enzymes and inhibits their activities ${ }^{(), 23), 24)}$. Work is in progress to investigate whether Rose Bengal inhibits RNA synthesis in the liver after oral administration of this dye to rats.

Both Amaranth and Ponceau 3R stimulated RNA synthesis in isolated hepatocytes (Fig. 2). We previously found that both azo dyes stimulate RNA synthesis in rat liver after oral administration ${ }^{15)}$. The results obtained from studies in isolated hepatocytes thus reflect the in vivo ones. On the other hand, the incorporation of radioactive orotic acid or adenine in vitro and in vivo is increased in the precancerous liver by prolonged feeding of a carcinogenic azo dye, N, N-dimethyl-4aminoazobenzene ${ }^{25)-27)}$. Further, $\mathrm{Wu}$ and Smuckler have reported that the administration of the carcinogenic azo dye results in enhanced RNA formation, enhanced chromatin binding of the RNA polymerase and 
the expression of previously repressed genomic segments ${ }^{28)}$, indicating that the azo dye may alter genetic expression by epigenetic means. However, the processes by which these changes are brought about are not known. Our previous paper ${ }^{29)}$ has shown that the chromatin of isolated rat liver nuclei treated with Amaranth and Ponceau 3R is highly susceptible to digestion by DNase I, suggesting that addition of the azo dyes may change the transcriptionally inactive form into the transcriptionally active form in nuclear chromatin. Many investigators have reported that the transcriptionally active chromatin is extremely susceptible to digestion by DNase $\mathrm{I}^{30}$. Moreover, our recent study has demonstrated that both Ponceau 3R and Amaranth stimulate RNA synthesis by causing the dissociation of heterochromatin in isolated rat liver nuclei*1.

Recent studies of chemical carcinogenesis have demonstrated that potential transforming genes are encoded in the genomes of normal mammalian cells ${ }^{31,32)}$. These data suggest that Ponceau 3R and Amaranth may activate the transforming genes that are repressed in the genomes of normal cells.

In conclusion, we investigated the use of isolated hepatocytes for studying the effects of coal tar dyes on viability, and RNA and protein syntheses. There are some limitations in this system. However, our results suggest that this system may be a good model of the liver for studying the action of food additives.

\section{References}

1) Matsushima, T.: "Gann" ed. by Yamamura, Y. and Sugimura, T., p. 23-28 (1979) Kyoritsu Shuppan, Tokyo.

2) Holtzman, J. L., Rothman, V., Margolis, S.: Biochem. Pharmac., 21, 581-584 (1972).

3) Gary, M. D., Hsieh, D. P. H., Byard, J. L.: Biochem. Biophys. Res. Commun., 78, 279-287 (1977).

4) Fry, J. R., Bridges, J. W.: Biochem. Pharmac., 26, 969-973 (1977).

5) Ernest, M. J., Chen, C. L., Feigelson, P.: J. Biol. Chem., 252, 6783-6791 (1977).

6) Yoshimoto, M., Okamoto, H., Hatano, S.,

*1 Yoshimoto, M., Yamaguchi, M., Hatano, S., Watanabe, T.: Fd Chem. Toxicol., in press.
Watanabe, T.: J. Food Hyg. Soc. Japan, 18, 154-158 (1977).

7) Ikeda, Y., Horiuchi, S., Furuya, T., Omori, Y.: Fd. Cosmet. Toxicol., 4, 485-492 (1966).

8) Hall, D. E,, Lee, F. S., Fairweather, F. A.: ibid., 4, 375-382 (1966).

9) Grice, H. C., Mannell, W. A., Allmark, M. G.: Toxic. Appl. Pharmac., 3, 509-520 (1961).

10) Aiso, K., Kanisawa, M., Okamoto, T., Chujo, T.: J. Food Hyg. Soc. Japan, 7, 211-221 (1966).

11) Andrianova, M. M.: Vop. Pitan., 29, 61-65 (1970).

12) Collins, T. F. X., McLaughlin, J.: Fd. Cosmet. Toxicol., 11, 355-365 (1973).

13) Khera, K. S., Przybylski, W., McKinley, W. P.: ibid., 12, 507-510 (1974).

14) Keplinger, M. L., Wright, P. L., Plank, J. P., Calandra, J. C.: Toxic. Appl. Pharmacol., 28, 209-215 (1974).

15) Yoshimoto, M., Hatano, S., Watanabe, T.: J. Food Hyg. Soc. Japan, 24, 408-410 (1983).

16) Yamasaki, Y., Ichihara, A.: Taisha, 12, 179 183 (1975).

17) Jezyk, P. F., Liberti, J. P.: Arch. Biochem. Biophys., 134, 442-449 (1969).

18) Lowry, O. H., Rosebrough, N. J., Farr, A. R., Randall, R. J.: J. Biol. Chem., 193, 265-275 (1951).

19) Fry, J. R., Janes, C. A., Wiebkin, P., Bellemann, P., Bridges, J. W.: Anal. Biochem., 71, 341-350 (1976).

20) Howard, R. B., Christensen, A. K., Gibbs, F. A., Pesh, L. A.: J. Cell Biol., 35, 675-684 (1967).

21) Berry, M. N., Friend, D. S.: ibid., 43, 506-520 (1969).

22) Seglen, P. O.: Exptl. Cell Res., 82, 391-398 (1973).

23) Brand, L., Gohlke, J. R., Rao, D. S.: Biochemistry, 6, 3510-3518 (1967).

24) Kido, K., Watanabe, T.: J. Food Hyg. Soc. Japan, 18, 238-243 (1977).

25) Rees, K. R., Rowland, G. F.: Biochem. J., 80, 428-433 (1961).

26) Kono, M.: Gann, 55, 251-257 (1964).

27) Rees, K. R., Rowland, G. F., Varcoe, J. S.: Brit. J. Cancer, 19, 72-82 (1965).

28) Wu, S. Y., Smuckler, E. A.: Cancer Res., 31, 239-247 (1971).

29) Yoshimoto, M., Suematsu, S., Hatano, S., Watanabe, T.: J. Food Hyg. Soc. Japan, 20, 192-197 (1979).

30) Weintraub, H., Groudine, M.: Science New York, 193, 848-856 (1976).

31) Spector, D. H., Varmus, H. E., Bishop, J. M.: Proc. Natl. Acad. Sci. U.S.A., 75, 4102-4106 (1978).

32) Cooper, G. M., Okenquist, S., Silverman, L.: Nature Lond., 284, 418-421 (1980). 